\title{
RECOVERY OF RICHNESS, BIOMASS AND DENSITY IN ATLANTIC RAINFOREST AREAS AFTER CLEARCUTTING ${ }^{1}$
}

\author{
Eliana Cardoso-Leite ${ }^{2 *}$, Ana Carolina Devides Castello ${ }^{3}$, Samuel Coelho ${ }^{4}$, Juliana Costa Coelho ${ }^{5}$, \\ Dimitrio Fernandes Schievenin ${ }^{6}$ and Janaina Braga do Carmo ${ }^{7}$
}

\footnotetext{
${ }^{1}$ Received on 19.06.2014 accepted for publication on 07.04.2016.

${ }^{2}$ Universidade Federal de São Carlos, Departamento de Ciências Ambientais, Sorocaba, São Paulo - Brasil. Email: <eliana.leite@ufscar.br>.

${ }^{3}$ Universidade Federal de São Carlos, Programa de Pós Graduação em Diversidade Biológica e Conservação, Sorocaba, São Paulo - Brasil. Email: <carol.dcastello@gmail.com>.

${ }^{4}$ Universidade Federal de São Carlos, Programa de Pós Graduação em Sustentabilidade na Gestão Ambiental, Sorocaba, São Paulo - Brasil. Email: <samucabeca@gmail.com>.

${ }^{5}$ Universidade de São Paulo, Pós-Graduação Interunidades em Ecologia Aplicada, Escola Superior de Agricultura "Luiz de Queiroz"-Centro de Energia Nuclear na Agricultura, Piracicaba, São Paulo - Brasil. Email: <julianaccoelho@hotmail.com>.

${ }^{6}$ Universidade Estadual Paulista, Pós- Graduação em Ciências Florestais, Botucatu, São Paulo - Brasil. Email:<dimitrio.eng@hotmail.com>.

${ }^{7}$ Universidade Federal de São Carlos, Departamento de Ciências Ambientais, Sorocaba, São Paulo - Brasil. Email:<jbcarmo@ufscar.br> .

*Corresponding author.
}

\begin{abstract}
Our aim was to analyze areas of Atlantic rainforest after clearcutting with different types of management (pasture establishment followed (PA) by abandonment and simple abandonment (NR)). We then compared composition parameters, structure and ecological processes with native forest as a reference. Our study was conducted in Sete Barras municipality, São Paulo State, Brazil. Data collection was performed six years after clearcutting, including all woody plants found in two strata (DBH (diameter at $1.3 \mathrm{~m}$ soil) $\geq 5 \mathrm{~cm}$ and $\mathrm{DBH}<5 \mathrm{~cm}$ and height $\geq 1.5 \mathrm{~m}$, respectively). PA and $\mathrm{RN}$ showed lower values of richness, density, basal area, and diversity index $\left(\mathrm{H}^{\prime}\right)$ when compared with $\mathrm{F}$ for both strata. Thus, independently of management type, six years of abandonment were not enough to recover the parameters analyzed, compared to native forest. Type of management influences ecological succession and structural parameters considering the second strata only.
\end{abstract}

Keywords: Abandoned pasture; Ecological succession; Natural regeneration.

\section{RECUPERAÇÃO DE RIQUEZA, BIOMASSA E DENSIDADE EM ÁREAS DE MATA ATLÂNTICA APÓS CORTE RASO}

\begin{abstract}
RESUMO - O objetivo deste estudo foi analisar áreas de Floresta Atlântica após corte raso com diferentes tipos de manejo (implantação de pasto seguido de abandono (PA) e simples abandono (NR)), comparando com floresta nativa parâmetros de composição, estrutura e processos ecológicos. O estudo foi realizado no município de Sete Barras, São Paulo, Brasil. A coleta de dados foi realizada seis anos após o corte raso, incluindo todas as plantas lenhosas encontradas em dois estratos (DAP (diâmetro à 1,30m do solo) $5 \mathrm{~cm}$ e DAP $<5 \mathrm{~cm}$ e altura $1.5 \mathrm{~m}$, respectivamente). PA e NR apresentaram menores valores de riqueza, densidade, área basal, e indice de diversidade $\left(H^{\prime}\right)$, quando comparado com o F para ambos os estratos. Por tanto, independentemente do tipo de manejo, seis anos de abandono nãoforam suficientes para recuperar os parâmetros analisados em comparação com a floresta nativa. No entanto, no segundo estrato, o tipo de manejo influenciou na sucessão ecológica e nos parâmetros estruturais.
\end{abstract}

Palavras-chave: Pastagem abandonada; Sucessão ecológica; Regeneração natural. 


\section{INTRODUCTION}

Atlantic rainforest is one of the most diverse ecosystem in terms of species diversity, with high rates of endemism (MYERS et al., 2000). However, this ecosystem has been destroyed for land conversion into agriculture areas (YOUNG, 2006). Approximately $50 \%$ of the remaining Atlantic rainforest in Brazil are located in Vale do Ribeira, São Paulo State, Brazil. This region has an economic activity based on agriculture, with banana production, palm hearts and livestock.

Due to the existence of specific legislation that protects the Brazilian Atlantic rainforest domain (BRASIL, 2006), and environmental factors (e.g. extremely wet climate), much of forested areas that had been cut for agricultural use, are left unused and forsaken. Removal of tropical forests and subsequent abandonment has originated secondary forests in different regeneration stages worldwide (GUARITAGUA; OSTERTAG, 2001; LAMB et al., 2005).

Studies in agricultural abandoned areas in Brazilian Atlantic rainforest showed that forest recovery following severe anthropogenic disturbances is not direct, predictable or even achievable on its own(SILVESTRINI et al., 2013). Appropriate actions and methods as planting ground covers, and enrichment with tree species were suggested (RODRIGUES; BRANCALION, 2009; CHEUNG et al., 2009, 2010) in order to restore natural forest regeneration process in abandoned old fields.

Thus, it is necessary to understand the dynamics of forest succession in abandoned areas after clearcutting, in order to facilitate the process of ecological restoration and management of these areas. Understanding composition, structure and functioning of these secondary forests have been the concern of several researchers (GUARITAGUA; OSTERTAG, 2001; LAMB et al., 2005; CHEUNG et al., 2009; CHEUNG et al., 2010). They attempted to answer questions such as: How long does it take to a secondary forest to recover the attributes of a mature forest? What is the speed of the ecological succession process in different conditions of climate and soil? (TABARELLI; MANTOVANI, 1999; LIEBSCH et al., 2008).

In this context, chronosequence studies in Brazil were performed by Tabarelli and Mantovani (1999), Liebsch et al. (2007) and Piotto (2009), and studies about succession in abandoned areas by Cheung et al. (2009), Cheung et al. (2010). In Vale do Ribeira region, where our study was conducted, there are few studies of this nature, except the one performed by Ainda et al (2001), about natural succession in different soil conditions.

Our aim was to analyze areas of Atlantic rainforest after clearcutting with different types of management (pasture establishment followed by abandonment and simple abandonment). We then compared composition parameters (richness and diversity), structure (density and biomass) and ecological processes (species successional groups) with native forest as a reference. We hypothesized that type of management after clearcutting has significant influence on recovery of parameters such as diversity and structure, and clearcutting followed by pasture implantation (fertilization and grass planting) slows the process of ecological succession compared with clearcutting followed by abandonment.

\section{MATERIALAND METHODS}

\subsection{Study area}

The study was conducted at São José Farm in Sete Barras municipality, São Paulo State, Brazil, which is part of the Atlantic rain forest domain with vegetation types of "dense rainforest lowland and submontane" (IBGE, 2012). Climate of the region is Af according to Köeppen classification and predominant soil type is hydromorphic cambisol (EMBRAPA, 2006). The farm is a private property and has a total area of 995.8 hectares. In 2005, several points of the farm were illegally deforested (BRASIL, 2006), and after legal intervention, those areas were abandoned. We studied the following conditions: pasture (PA) - forest clearcutting followed by pasture establishment and abandonment; natural regeneration (NR) - forest clearcutting and abandonment; which were then compared with native forest $(\mathrm{F})$ in surrounding areas (Figure 1). From now on, these areas will be referred as treatments PA, NR, F respectively.

\subsection{Data collection}

Data collection was performed six years after deforestation. Phytosociological survey was conducted using plot method(MUELLER-DOMBOIS; ELLENBERG, 1974) including all woody plants found in two strata. For the first stratum (diameter at $1,30 \mathrm{~m}$ soil (DBH) $\geq 5 \mathrm{~cm}$ ) five plots of $20 \times 20 \mathrm{~m}$ were used for each area, totalizing 15 plots of $20 \times 20 \mathrm{~m}$ or $6000 \mathrm{~m}^{2}$. For the second stratum $(\mathrm{DBH}<5 \mathrm{~cm}$ and height $\geq 1.5 \mathrm{~m}) 2 \times 20 \mathrm{~m}$ transects were used in the center of the 15 plots of $20 \times 20 \mathrm{~m}$. Total 


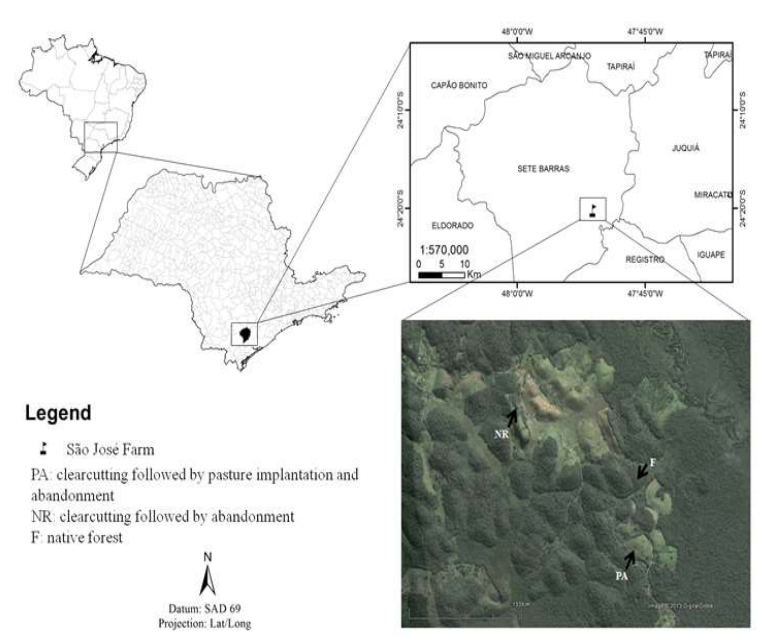

Figure 1 - Study area location in Brazil, São Paulo State and location of treatments $(\mathrm{F}=$ forest, $\mathrm{NR}=$ natural regeneration after clearcutting and abandonment, $\mathrm{PA}=$ pasture). São José Farm, Sete Barras, SP, Brazil.

Figura 1 - Localização da área de estudo no Brasil, Estado de São Paulo, e a localização dos tratamentos $(F=$ floresta,$N R=$ regeneração natural após corte raso e abandono, $P A=$ pasto abandonado). Fazenda São José, Sete Barras, SP, Brasil.

height, shaft height and DBH were measured and botanical material was collected for identification.

Species were identified using dichotomous keys, literature to the assessed taxa, comparisons with material deposited in herbaria of Universidade Federal de São Carlos, campus Sorocaba (SORO) and assistance from experts. Species were identified using APG III (2009). Spellings of species names and authors were checked using database of the Brazilian Flora Checklist (LISTA DE ESPÉCIES DAFLORADO BRASIL, 2013). Vouchers were deposited in the Herbarium of Universidade Federal de São Carlos, campus Sorocaba. Pioneer species were identified as $\mathrm{Pi}$ and non-pioneer as $\mathrm{NPi}$, according to Whitmore's (1989) classification. In each area, random points were chosen to collect composite soil samples at 0 to $20 \mathrm{~cm}, 20$ to $40 \mathrm{~cm}$ and 40 to $60 \mathrm{~cm}$ depths for physicochemical analyses.

\subsection{Data Analysis}

Phytosociological parameters (MUELLERDOMBOIS; ELLENBERG, 1974) were calculated using Fitopac 2.1 (SHEPERD, 2009), where each plot was considered as a sampling unit, so each treatment (PA,
NR and F) had five replicates. Values of total density, basal area and the Shannon index were estimated from five plots of each treatment. Richness total richness was calculated by summing total species sampled in all plots. We also use diversity profile analysis to compare richness and evenness among areas (F, NR and PA), not just describe them. When alpha $(\alpha)$ is equal to " 1 " it is equivalent to the Shannon diversity index and when alpha is equal to " 2 " is equivalent to the Simpson diversity index, and alfa equal to " 0 " corresponds to the richness of the evaluated areas (TOTHMERESZ, 1995). Thus, we compared evenness ( $\alpha$ values $\geq 2$ ) and richness ( $\alpha$ values $\geq 1$ ). The diversity profile was elaborated using PAST software (HAMMER et al., 2001). Soil parameters were analyzed using ANOVA and the means were compared by Tukey's test $(\mathrm{p}<0.05)$.

\section{RESULTS}

One hundred and twenty-eight species belonging to 27 families were recorded (Table 1). In PA, two species were recorded in the first stratum, and 6 in the second; in NR, 13 species in the first stratum and 25 in the second; and in F, 101 species in the first stratum and 58 in the second (Table 2). Families with the highest species richness were (Table 1) Myrtaceae (24 spp.), Lauraceae (11 spp.), Rubiaceae (10 spp.) and Melastomataceae (7 spp.), and only Chromolaena laevigata (Lam.) R.M.King \& H.Rob., Senna multijuga (Rich.) H.S. Irwin \& Barneby and Pera glabrata (Schott) Poepp. ex Baill. were sampled in all treatments. The highest diversity ( $\mathrm{H}^{\prime}$ ) was found in F, followed by NR and PA (Table 2, Figure 2).

Richness, density and basal area, and percentage of species successional groups are presented in Table 2, and soil analyses results are shown in Table 3 . Comparisons between diversity and evenness among areas and strata are shown in Figure 2.

\section{DISCUSSION}

PA and NR showed lower values of richness, density, basal area, and diversity index $\left(\mathrm{H}^{\prime}\right)$ when compared with F (Tab. 2, Figure 2), for both strata. Forest (first strata) had relatively high $\mathrm{H}^{\prime}$ (4.03), which are comparable to other studies in Atlantic rainforest at the same region (GUILHERME et al., 2004; MAMEDE et al., 2004; CARDOSO-LEITE et al., 2013).

Revista Árvore, Viçosa-MG, v.40, n.3, p.499-508, 2016 
Table 1 - Species sampled in different treatments. $\mathrm{F}=$ forest, $\mathrm{NR}=$ natural regeneration after clearcutting and abandonment, $\mathrm{PA}=$ abandoned pasture. 1 - first stratum, 2 - second stratum. $\mathrm{Pi}=$ pionner species, $\mathrm{NPi}=$ non pionner species, $\mathrm{SC}=$ unclassified. *alien species. São José Farm, Sete Barras, SP, Brazil.

Tabela 1 - Espécies amostradas nos diferentes tratamentos. $F=$ floresta, $N R=$ regeneração após corte e abandono, PA= pasto abandonado. 1 - Primeiro estrato, 2-segundo estrato. $P i=$ espécies pioneiras, $N P i=$ espécies não pioneiras, $S C=$ não identificadas. *Espécies exóticas. Fazenda São José, Sete Barras, SP, Brasil.

\begin{tabular}{|c|c|c|c|c|c|c|c|}
\hline \multirow[t]{2}{*}{ Família } & \multirow[t]{2}{*}{ Nome Científico - grupo ecológico (P eNP) } & \multicolumn{2}{|c|}{ PA } & \multicolumn{2}{|c|}{ NR } & \multicolumn{2}{|c|}{$\mathrm{F}$} \\
\hline & & 1 & 2 & 1 & 2 & 1 & 2 \\
\hline ANACARDIACEAE & Tapirira guianensis Aubl. - P & & & $\mathrm{X}$ & & $\mathrm{X}$ & \\
\hline ANNONACEAE & $\begin{array}{l}\text { Annona neosericea H.Rainer - P } \\
\text { Guatteria australis A.St.-Hil. - NP } \\
\text { Xylopia brasiliensis Spreng. -NP }\end{array}$ & & & $\mathrm{X}$ & & $\begin{array}{l}\mathrm{X} \\
\mathrm{X}\end{array}$ & $\mathrm{X}$ \\
\hline APOCYNACEAE & $\begin{array}{l}\text { Malouetia cestroides (Nees ex Mart.) } \\
\text { Müll.Arg. - P }\end{array}$ & & & & & $\mathrm{X}$ & \\
\hline ARALIACEAE & $\begin{array}{l}\text { Dendropanax monogynus (Vell.) Seem. - P } \\
\text { Schefflera angustissima (Marchal) Frodin - P }\end{array}$ & & & & & $\mathrm{X}$ & $\bar{X}$ \\
\hline ARECACEAE & $\begin{array}{l}\text { Astrocaryum aculeatissimum (Schott) } \\
\text { Burret - NP } \\
\text { Euterpe edulis Mart. - NP }\end{array}$ & & & & & $\mathrm{X}$ & $\mathrm{X}$ \\
\hline ASTERACEAE & $\begin{array}{l}\text { Chromolaena laevigata (Lam.) R.M.King } \\
\text { \& H.Rob. - SC } \\
\text { Vernonanthura discolor (Spreng.) H.Rob. - P } \\
\text { Vernonanthura divaricata (Spreng.) H.Rob.- P }\end{array}$ & & $\mathrm{X}$ & $\mathrm{X}$ & $\begin{array}{l}X \\
X\end{array}$ & $\mathrm{X}$ & \\
\hline BIGNONIACEAE & $\begin{array}{l}\text { Jacaranda } \mathrm{sp} .1-\mathrm{SC} \\
\text { Jacaranda } \mathrm{sp} .2-\mathrm{SC}\end{array}$ & & $\mathrm{X}$ & & & $\mathrm{X}$ & \\
\hline BORAGINACEAE & $\begin{array}{l}\text { cf. Cordia magnoliifolia } \text { Cham. - SC } \\
\text { Cordia sellowiana Cham. - P }\end{array}$ & & & & & $\begin{array}{l}\mathrm{X} \\
\mathrm{X}\end{array}$ & $\mathrm{X}$ \\
\hline CELASTRACEAE & $\begin{array}{l}\text { Maytenus gonoclada Mart. - NP } \\
\text { Maytenus sp. - SC }\end{array}$ & & & & & $\mathrm{X}$ & $\begin{array}{l}\mathrm{X} \\
\mathrm{X}\end{array}$ \\
\hline CHRYSOBALANACEAE & $\begin{array}{l}\text { Hirtella hebeclada Moric. ex DC. - NP } \\
\text { cf. Licania } \text { sp. -SC } \\
\text { Licania } \text { cf. Kunthiana Hook. f. - NP }\end{array}$ & & & & & $\begin{array}{l}\mathrm{X} \\
\mathrm{X} \\
\mathrm{X}\end{array}$ & \\
\hline CLUSIACEAE & Garcinia brasiliensis Mart. - NP & & & & & $\mathrm{X}$ & \\
\hline ELAEOCARPACEAE & Sloanea guianensis (Aubl.) Benth. - NP & & & & & $\mathrm{X}$ & $\bar{X}$ \\
\hline EUPHORBIACAE & $\begin{array}{l}\text { Alchornea glandulosa Poepp. \& Endl.- P } \\
\text { Hevea brasiliensis (Willd. ex A. Juss.) } \\
\text { Müll. Arg. * - NP } \\
\text { Sapium glandulosum (L.) Morong - P } \\
\text { Tetrorchidium rubrivenium Poepp. - P }\end{array}$ & $\mathrm{X}$ & & $\begin{array}{l}X \\
X \\
X\end{array}$ & $\mathrm{X}$ & $\mathrm{X}$ & $\mathrm{X}$ \\
\hline FABACEAE-CAESALPINIOIDEAE & $\begin{array}{l}\text { Senna multijuga (Rich.) H.S. } \\
\text { Irwin \& Barneby - P }\end{array}$ & & $\mathrm{X}$ & $\mathrm{X}$ & $\mathrm{X}$ & & $\mathrm{X}$ \\
\hline FABACEAE-FABOIDEAE & $\begin{array}{l}\text { Andira anthelmia (Vell.) Benth. - NP } \\
\text { Andira fraxinifoliaBenth. - NP } \\
\text { Dahlstedtia pinnata (Benth.) Malme - NP } \\
\text { Machaerium brasiliense Vogel - NP } \\
\text { Machaerium sp. - SC } \\
\text { Swartzia acutifólia Vogel - NP }\end{array}$ & & & $\mathrm{X}$ & $\mathrm{X}$ & $\begin{array}{l}X \\
X \\
X \\
X \\
X\end{array}$ & $\begin{array}{l}X \\
X\end{array}$ \\
\hline FABACEAE-MIMOSOIDEAE & $\begin{array}{l}\text { Albizi apedicellaris (DC.) L.Rico-SC } \\
\text { Inga edulis Mart. - NP }\end{array}$ & & & & $\mathrm{X}$ & $\begin{array}{l}\mathrm{X} \\
\mathrm{X}\end{array}$ & \\
\hline LACISTEMATACEAE & Lacistema lucidum Schnizl. - NP & & & & & $\mathrm{X}$ & \\
\hline LAMIACEAE & $\begin{array}{l}\text { Aegiphila integrifólia (Jacq.) Moldenke - P } \\
\text { Vitex sellowiana Cham. - SC }\end{array}$ & & & $\mathrm{X}$ & $\mathrm{X}$ & $\begin{array}{l}X \\
X\end{array}$ & \\
\hline
\end{tabular}

Revista Árvore, Viçosa-MG, v.40, n.3, p.499-508, 2016 
Table 1...

Tabela 1...

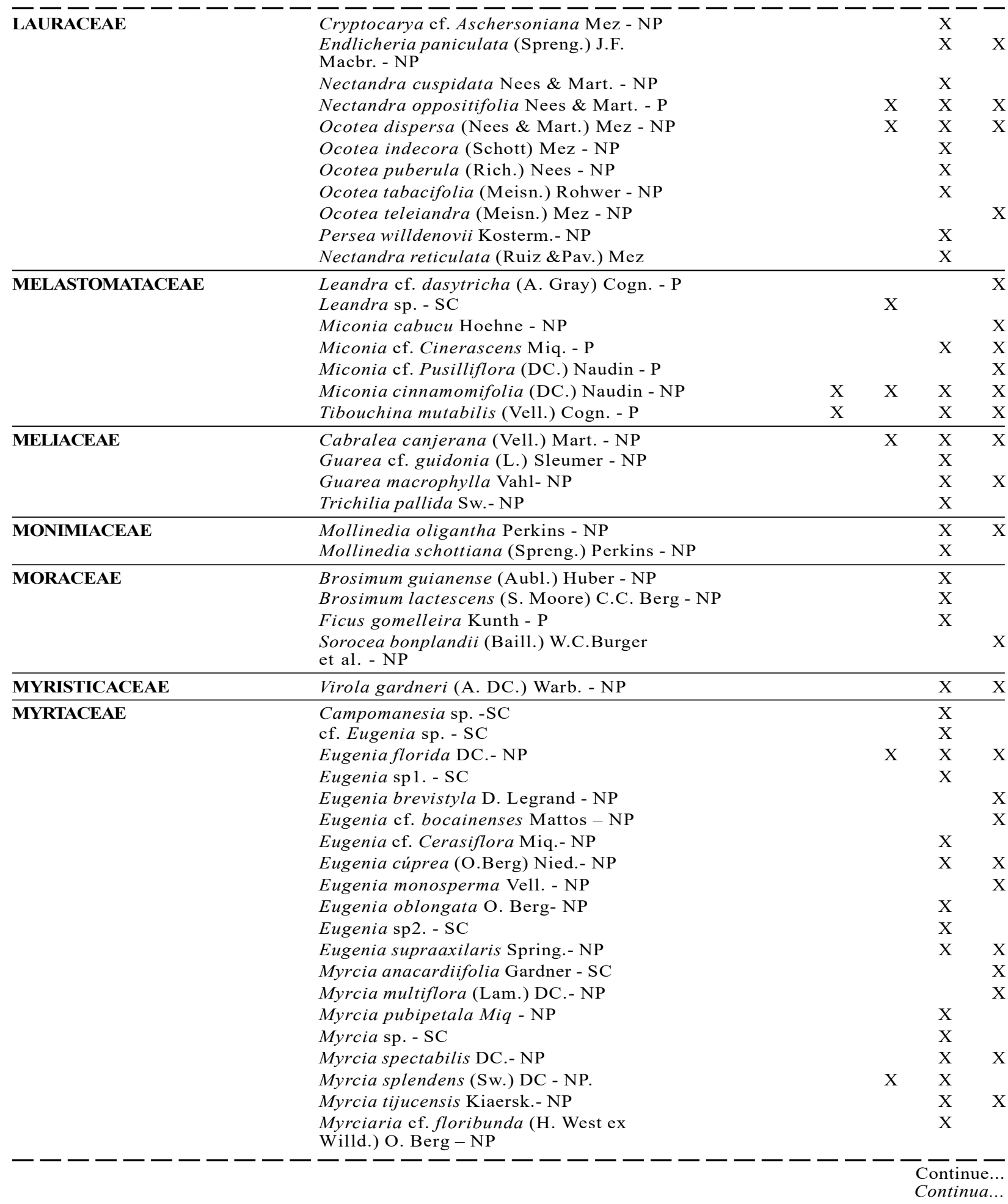


Table 1...

Tabela 1...

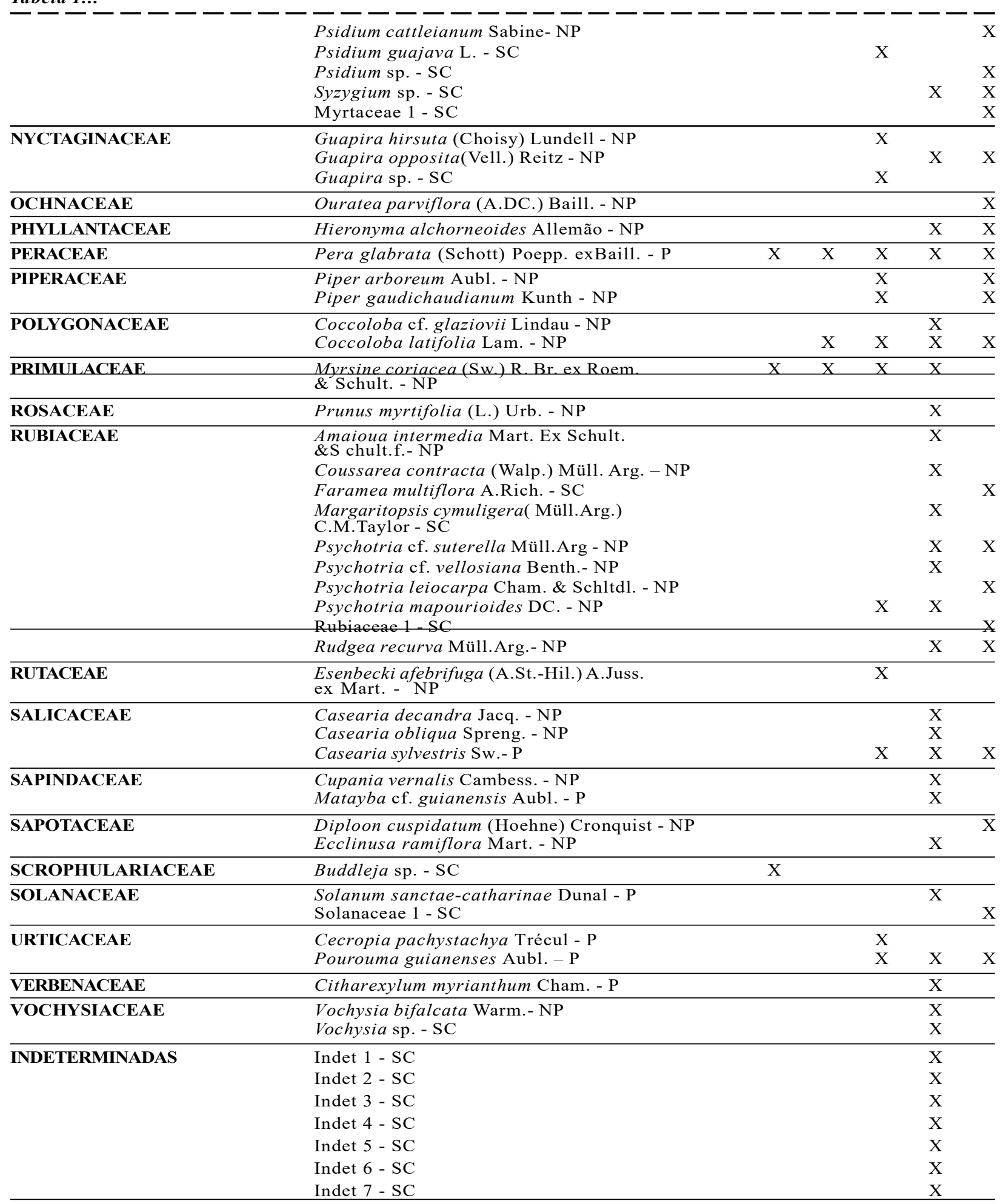

Revista Árvore, Viçosa-MG, v.40, n.3, p.499-508, 2016 
Table 2 - Results of richness, density, basal area, $\mathrm{H}^{\prime}$ and percentage of species in successional groups, for two strata analyzed. $\mathrm{F}=$ forest, $\mathrm{NR}=$ natural regeneration after clearcutting and abandonment, $\mathrm{PA}=$ abandoned pasture. 1 - first stratum, 2 - second stratum. $\mathrm{Pi}=$ pionner species, $\mathrm{NPi}=$ non pionner species. São José Farm, Sete Barras, SP, Brazil.

Tabela 2 - Resultados de riqueza, densidade, área basal, $H^{\prime}$ e porcentagem de espécies dos grupos sucessionais, para os dois estratos analisados. $F=$ floresta, $N R=$ regeneração após corte e abandono, $P A=$ pasto abandonado. 1 Primeiro estrato, 2- segundo estrato. $P i=$ espécies pioneiras, $N P i=$ espécies não pioneiras. Fazenda São José, Sete Barras, SP, Brasil.

\begin{tabular}{|c|c|c|c|c|c|c|}
\hline $\begin{array}{c}\text { Treatment } \\
\text {-stratum }\end{array}$ & Richness & $\begin{array}{c}\text { Density } \\
\text { (n.ind./ha) }\end{array}$ & $\begin{array}{c}\text { Basal area } \\
\left(\mathrm{m}^{2} / \mathrm{ha}\right)\end{array}$ & $\mathrm{H}^{\prime}$ & Equitability & $\% \mathrm{Pi}-\% \mathrm{NPi}$ \\
\hline PA-1 & 2 & 55 & 0.55 & 0.59 & 0,845 & $50-50$ \\
\hline NR-1 & 13 & 280 & 4.55 & 2.16 & 0,817 & $61.5-30.8$ \\
\hline F-1 & 101 & 1765 & 29.8 & 4.03 & 0,871 & $18.8-60.4$ \\
\hline PA-2 & 6 & 220 & 0.05 & 1.21 & 0,620 & $50-0$ \\
\hline NR-2 & 4 & 470 & 0.15 & 2.44 & 0,759 & $28.0-56.0$ \\
\hline $\mathrm{F}-2$ & 58 & 725 & 0.25 & 3.62 & 0,892 & $15.5-65.5$ \\
\hline
\end{tabular}

Table 3 - Results of soil analysis. $\mathrm{F}=$ forest, $\mathrm{NR}=$ natural regeneration after clearcutting and abandonment, $\mathrm{PA}=$ abandoned pasture. 0 to $20 \mathrm{~cm}, 20$ to $40 \mathrm{~cm}$ and 40 to $60 \mathrm{~cm}$ are depths which the collection of soil samples were carried out. São José Farm. Sete Barras. SP. Brazil.

Tabela 3 - Resultados das análises de solo. $F=$ floresta, $N R=$ regeneração natural após corte raso e abandono, $P A=$ pasto abandonado. 0 a $20 \mathrm{~cm}, 20$ a $40 \mathrm{~cm}$ e 40 a $60 \mathrm{~cm} \mathrm{~cm}$ são as profundidades nas quais foram feitas as coletas de amostras de solo. Fazenda São José. Sete Barras. SP. Brasil.

\begin{tabular}{|c|c|c|c|c|c|c|c|c|c|c|c|c|c|c|c|c|c|c|c|c|}
\hline $\begin{array}{l}\text { Area/ } \\
\text { Depth }\end{array}$ & M.O. & $\mathrm{H}$ & $\mathrm{P}$ & $\mathrm{K}$ & $\mathrm{Ca}$ & $\mathrm{Ig}$ & Al & $+\mathrm{Al}$ & B. & C.T.C. & $\mathrm{V} \%$ & $\mathrm{~S}$ & B & $\mathrm{Cu}$ & $\mathrm{Fe}$ & $\mathrm{Mn}$ & $\mathrm{Zn}$ & Clay & Sand & Silt \\
\hline & $\mathrm{g} / \mathrm{dm}^{3}$ & & $\mathrm{mg} / \mathrm{d}$ & & & & 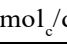 & , & & & $\%$ & & & $\mathrm{mg}$ & $\mathrm{dm}^{3}$ & & & & 0 & \\
\hline A/ $0-20$ & $21 \mathrm{a}$ & $5 \mathrm{a}$ & $4 a$ & $0.4 \mathrm{a}$ & $19 a$ & $5 \mathrm{a}$ & $2 a$ & $47 a$ & $24 \mathrm{a}$ & $71 \mathrm{a}$ & $34 a$ & $6 a$ & 0.2 & $0.1 \mathrm{c}$ & $206 a$ & $1.2 \mathrm{a}$ & $0.3 \mathrm{a}$ & $20.5 \mathrm{a}$ & $66.3 \mathrm{a}$ & $13 a$ \\
\hline $\mathrm{R} / 0-20$ & $19 a$ & $4 a$ & $2 b$ & $4 \mathrm{a}$ & $9 b$ & $3 b$ & $17 b$ & 3 & $13 b$ & $44 b$ & $30 a$ & $13 b$ & $0.3 \mathrm{a}$ & $0.2 \mathrm{c}$ & $100 \mathrm{~b}$ & $1.6 \mathrm{a}$ & $0.4 \mathrm{a}$ & $39.3 b$ & $32.8 b$ & $28 b$ \\
\hline$/ 0-20$ & $31 \mathrm{c}$ & $4 a$ & $7 \mathrm{c}$ & $0.6 \mathrm{a}$ & $3 c$ & $3 b$ & $27 \mathrm{c}$ & $\mathrm{c}$ & $5.9 \mathrm{c}$ & $156 \mathrm{c}$ & $4 b$ & $17 \mathrm{c}$ & a & $\mathrm{c}$ & $153 \mathrm{c}$ & $0.9 \mathrm{a}$ & $0.5 \mathrm{a}$ & $3 \mathrm{c}$ & $50.8 \mathrm{c}$ & $16 \mathrm{c}$ \\
\hline 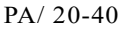 & $17 \mathrm{~A}$ & $4 \mathrm{~A}$ & A & & $9 \mathrm{~A}$ & 3 & 7 & & & & $19 \mathrm{~A}$ & $10 \mathrm{~A}$ & & & & & & & & $15 \mathrm{~A}$ \\
\hline 40 & $21 \mathrm{~B}$ & $4 \mathrm{~A}$ & $3 \mathrm{~A}$ & $4 \mathrm{~A}$ & $14 \mathrm{~B}$ & $5 \mathrm{~B}$ & $10 \mathrm{~B}$ & & $19 B$ & $91 \mathrm{~B}$ & $21 \mathrm{~A}$ & $9 \mathrm{~A}$ & 0 & $2.7 \mathrm{~B}$ & 15 & $1.7 \mathrm{~B}$ & $12 \mathrm{~B}$ & $44.3 \mathrm{~B}$ & $36 \mathrm{~B}$ & $20 \mathrm{~B}$ \\
\hline$/ 20$ & $20 \mathrm{~B}$ & $4 \mathrm{~A}$ & $3 \mathrm{~A}$ & $0.3 \mathrm{~A}$ & $2 \mathrm{C}$ & $1 \mathrm{C}$ & $28 \mathrm{C}$ & $135 \mathrm{C}$ & $3.8 \mathrm{C}$ & $139 \mathrm{C}$ & 3B & $18 \mathrm{~B}$ & $0.4 \mathrm{~A}$ & $0.1 \mathrm{C}$ & $101 \mathrm{C}$ & $0.6 \mathrm{C}$ & $0.4 \mathrm{C}$ & $42 \mathrm{~B}$ & $45.5 \mathrm{C}$ & $12 \mathrm{C}$ \\
\hline A/ $40-60$ & 15á & 4á & lá & $0.3 a ́$ & 4á & 1á & 15á & 72 á & 5.7á & 77á & 7á & 19á & $0.2 a ́$ & $0.1 a ́$ & 188á & 1.1á & $0.2 a ́$ & 9á & 58.7á & 12á \\
\hline NR /40-60 & 16á & 4á & lá & 0.3á & $5 a ́$ & 2á & 18â & $88 \mathrm{â}$ & 7.2â & 96â & $8 a ́$ & $28 \mathrm{a}$ & 0.3á & 0.1 á & $45 \hat{a}$ & 0.8 á & 0.3á & 44.8â & 28.9â & 26â \\
\hline F $40-60$ & 16á & 4á & 2á & $0.3 a ́$ & 2â & 1á & $25 \& !$ & $109 \& !$ & $2.4 \& !$ & $112 \& !$ & 2â & $39 \& !$ & $0.3 a ́$ & $0.1 a ́$ & $23 \& !$ & $0.4 a ̂$ & 0.1 á & 49â & $37.7 \& !$ & 13á \\
\hline
\end{tabular}

$\mathrm{SB}=$ sum of bases. $\mathrm{CEC}=$ cation exchange capacity. $\mathrm{V} \%=$ saturation. $\mathrm{M} . \mathrm{O}=$ organic matter. Values in the column with distinct letters and symbols are statistically different $(n=5)$, considering the comparison of data inside of each deph separately.

$\mathrm{SB}=$ soma de bases. $\mathrm{CEC}=$ capacidade de troca catiônica. $\mathrm{V}=\%$ de saturação. $\mathrm{M} . \mathrm{O}=$ matéria orgânica. Os valores na coluna com letras distintas e símbolos são estatisticamente diferentes $(n=5)$, considerando a comparação dos dados de cada área dentro de cada profundidade separadamente.

Pascarella et al. (2000) studying natural regeneration in abandoned cropland, found richness of 7 to 11 species, basal area of 4.1 to $8.4 \mathrm{~m}^{2} /$ ha and $\mathrm{H}^{\prime}$ of 1.12 to 1.59 in areas with four years of abandonment $(\mathrm{DBH}>1 \mathrm{~cm}$ as inclusion criterion). The criteria used by Pascarella et al. (2000) are comparable to our first and second strata of NR and PA analyzed together, so those results are similar to ours.

Cheung et al. (2010) recorded that recovery of recently abandoned pasture in southeastern Brazil is a fast and efficient process, resulting in a young and structured forest. In these areas, while abundance of trees, species richness and volume increases with time of abandonment, abundance of shrubs decreases. Our results agree with these authors, because in PA and NR we sampled an expressive amount of shrubs in the second stratum (Table 2, density), indicating that forest recovery starts with shrubs.

Abundance of shrubs decreases with time of abandonment (CHEUNG et al., 2010) because canopy is closing and shadowing. Conversely, shrub species richness in understory increases as the forest ages. Young forest (less than 20 years) has 6 to $30 \%$ of species in understory, while in older forests (50 to 120 years) 


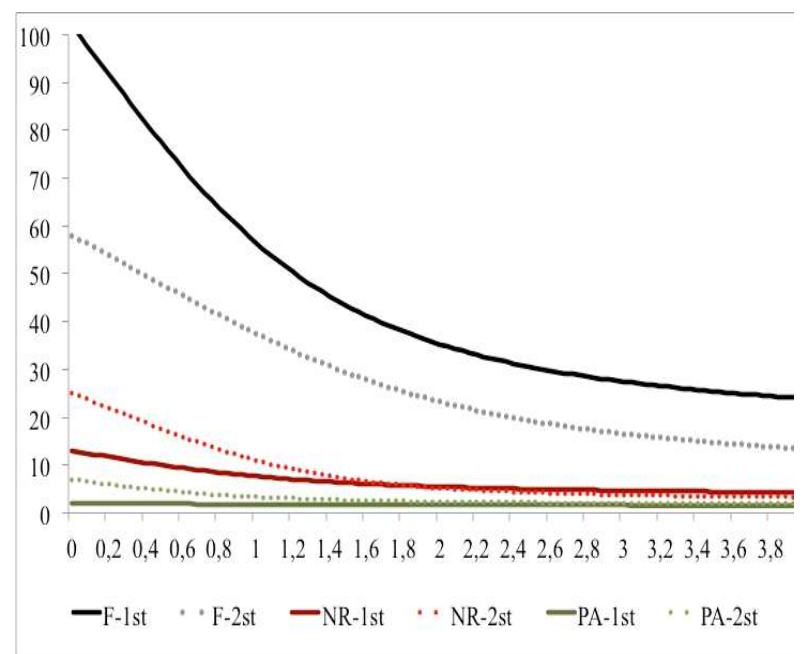

Figure 2 - Diversity profiles comparing the study areas (PA, NR and F) located in São José Farm, Sete Barras (SP), inserted in the Atlantic rainforest domain. $\mathrm{PA}=$ pasture; $\mathrm{NR}=$ natural regeneration; $\mathrm{F}=$ Forest. São José Farm, Sete Barras, SP, Brazil

Figura 2-Perfil de diversidade comparando as áreas de estudo (PA, NR e F) localizadas na Fazenda São José, Sete Barras (SP), inseridas no domínio Mata Atlântica. $P A=$ pasto; $N R=$ regeneração natural; $F=$ floresta . Fazenda São José, Sete Barras, SP, Brasil.

this percentage increases to 44 to $54 \%$ (LIEBSCH et al., 2008). In F, 45,3\% of total species were found in the second stratum, indicating that native forest used for comparison is in an intermediate successional stage.

According to Tabarelli and Mantovani (1999), species richness and diversity recover faster than physical structure attributes, such as basal area and volume. Our data do not agree with these authors, possibly because they studied natural regeneration in older forests (10, 18 and 40 years) than our areas and without different management actions, which may have influenced the differences found.

The basal area was greater in the first layer in the NR (as seen in F), in comparison with PA (Table 2). On the other hand, the density was higher in the second layer in NR, indicating that the natural recovery is occurring (Table 2) but abandonment of time also allowed richness recovery and basal area in the second stratum. Thus, it is apparent that the rich recovery diversity and density in the PA and NR first starts after leaving the second layer over the first layer.

Revista Árvore, Viçosa-MG, v.40, n.3, p.499-508, 2016
Compared to adjacent native forest $(\mathrm{F})$ there is an evident decrease in percentage of latter species (NPi) for both strata in PA and NR (Table 2). In addition, in the second stratum of PA only pioneer species (Pi) were sampled, indicating that pasture establishment (PA) delayed successional process. Piotto (2009) found 20 to $35 \%$ of NPi species (late secondary and climax) in a chronosequence study in Atlantic rainforest, while Tabarelli;Mantovani (1999) found 25\% of NPi species in a young forest and $90 \%$ of NPi species in a mature forest; Liesbch et al. (2008) also observed $90 \%$ of NPi species in mature Atlantic rainforests. We found 60,4\% of NPi species in F (Table 2), indicating that the native forest $(F)$ used as the reference is in an intermediate stage.

Soil analyses (Table 3 ) indicated that in PA, soil has high quantities of $\mathrm{Fe}$ and $\mathrm{Ca}$, the latter due to liming. In NR, chemical characteristics were intermediate between $\mathrm{F}$ and PA. In regards to physical characteristics, PA has high quantity of sand, which might be a consequence of erosion in surrounding areas, and NR is more clayey, similar to forest (F). Forest soil, despite its higher levels of Al, showed higher levels of organic matter and cation exchange capacity. Although the type of soil is the same in F, NR and PA, differences in management affected soil quality. This may have been caused by fertilizer application which favored grasses establishment (in PA), and consequently the recovery of natural vegetation in this treatment was slower than in the other (NR).

\section{CONCLUSION}

Simple abandonment and pasture establishment followed by abandonment affected negatively the forest canopy. In the first stratum (canopy), none of the analyzed parameters showed recovery for both areas. However, for the second stratum (shrubs), simple abandonment allowed faster recovery than pasture establishment followed by abandonment. Therefore, our hypothesis was supported.

Our study suggests that areas with clearcutting and pasture implementation require more intense management for its restoration. Techniques such as enrichment with seedling planting, direct sowing or topsoil translocation could be implemented. On the other hand, given enough time, areas subjected to clearcutting followed by abandonment can recover on its own by passive restoration. 


\section{ACKNOWLEDGMENTS}

We thank the Public Ministry of São Paulo State, and the Fundação de Apoio Institucional ao Desenvolvimento Científico e Tecnológico (FAI, process number 1340-2) for funding the project.

\section{REFERENCES}

AIDAR, M.P.M.; GODOY, J.R.L.; BERGMANN, J. Atlantic Forest succession over calcareous soil, Parque Estadual Turístico do Alto RibeiraPETAR, SP. Revista Brasileira de Botânica, v.24, n.4, p.445-469, 2001.

APG III. An update of the Angiosperm Phylogeny Group classification for the orders and families of flowering plants. Botanical Journal of the Linnean Society, v.161, p.105-202, 2009 .

BRASIL. Lei No 11.428 , de 22 de dezembro de 2006. Dispõe sobre a utilização e proteção da vegetação nativa do Bioma Mata Atlântica, e dá outras providências. Publicado no D.O.U. em 26/12/2006, 2006.

CARDOSO-LEITE,E.; PODADERA, D.S.; PERES,J.C.; CASTELLO, A.C.D. Analysis of floristic composition and structure as an aid to monitoring protected areas of dense rain forest in southeastern Brazil. Acta Botanica Brasilica, v.27, n.1, p.180-194, 2013.

CHEUNG, K.C.; MARQUES, M.C.M.; LIEBSCH, D. Relação entre a presença de vegetação herbácea e a regeneração natural de espécies lenhosas em pastagens abandonadas na Floresta Ombrófila Densa do Sul do Brasil. Acta Botanica Brasilica, v.23, n.4, p.1048-1056, 2009.

CHEUNG, K.C.; LIEBSCH, D.; MARQUES, M.C.M. Forest recovery in newly abandoned pasture in southern Brazil: implications for the Atlantic Forest resilience. Natureza \& Conservação, v. 8, n.1, p.66-70, 2010.

EMPRESA BRASILEIRA DE PESQUISA AGROPECUÁRIA - EMBRAPA. Sistema brasileiro de classiûcação de solos. Rio de Janeiro: 2006.

GUARITAGA, M.R.; OSTERTAG, R. Neotropical secondary Forest succession: changes structural and functional characteristics. Forest Ecology and Management, v.148, p.185206, 2001

GUILHERME, F.A.; MORELLATO, L.P.C.; ASSIS, M.A. Horizontal and vertical tree community structure in a section of lowland Atlantic Rain Forest in the Intervales State Park, southeastern Brazil. Revista Brasileira de Botânica, v.27, n.4, p.725-737, 2004.

HAMMER, O.; HARPER, D.A.T.; RYAN, P.D. PAST: Paleontological Statistics Software Package for Education and Data Analysis. 2001.9p. (Palaeontologia Electronica, 4)

Instituto Brasileiro de Geografia e Estatística IBGE. Manual técnico da vegetação brasileira. Rio de Janeiro: IBGE, 2012.

LAMB, D.; ERSKINE, P.D.; PARROTTA, J.A. Restoration of degraded tropical forest landscapes. Science, v.310, p.1628-1632, 2005.

LIEBSCH, D.; GOLDENBERG, R.; MARQUES, M.C.M. Florística e estrutura de comunidades vegetais em uma cronoseqüência de Floresta Atlântica no Estado do Paraná, Brasil. Acta Botanica Brasilica, v.21, n.4, p.983-992, 2007.

LIEBSCH, D.; MARQUES, M.C.M.; GOLDENBERG, R. How long does the Atlantic Rain Forest take to recover after a disturbance? Changes in species composition and ecological features during secondary succession. Biological Conservation, v. 141, p.1717-1725, 2008.

LISTA DE ESPÉCIES DA FLORA DO BRASIL. Jardim Botânico do Rio de Janeiro: 2013. Available from: http://floradobrasil.jbrj.gov.br/. Cited 2013 Oct 20,2013

MAMEDE,M.C.H.; CORDEIRO,I.; ROSSI,L.; MELO,M.M.R.F.; OLIVEIRA, R.J. Mata Atlântica. In: Marques, O.A.V.; Duleba, W. (Ed.) Estação Ecológica Juréia-Itatins: ambiente físico, flora e fauna. Ribeirão Preto: Holos, 2004. p.115132

SILVESTRINI,M.; CYSNEIRO,A.D.; LIMA,A.L.; VEIGA,L.G.; ISERNHAGEN,I.; TAMASHIRO,J.Y.; GANDOLFI,S.; RODRIGUES,R.R. Natural regeneration in abandoned fields following

Revista Árvore, Viçosa-MG, v.40, n.3, p.499-508, 2016 
intensive agricultural land use in an Atlantic Forest Island., Brazil. Revista Árvore, v.36, n.4, p.659-671, 2012.

MUELLER-DOMBOIS, D.; ELLENBERG, G.H. Aims and methods of vegetation ecology. New York: Willey \& Sons, 1974.

MYERS,N.; MITTERMEIER,R.A.; MITTERMEIER,G.G.; FONSECA,G.A.; KENT,J. Biodiversity hotspots for conservation priorities. Nature, v.403, p.853-858, 2000.

PASCARELLA,J.B.; AIDE,T.M.; SERRANO,M.I.; ZIMMERMAN,J.K. Land-use History and Forest Regeneration in the Cayey Mountains, Puerto Rico. Ecosystems, v.3, p.217-228, 2000

PIOTTO, D.; MONTAGNINI,F.; THOMAS,W.; ASHTON, M.; OLIVER,C. Forest recovery after swidden cultivation across a 40 -year chronosequence in the Atlantic forest of southern Bahia, Brazil. Plant Ecology, v.205, p.261-272, 2009.

RODRIGUES, R.R.; BRANCALION, P.H.S. (Org.). Pacto pela restauração da mata atlântica: referencial dos conceitos e ações de restauração florestal. Ingo Isernhagen. São Paulo: LERF/ ESALQ: Instituto BioAtlântica, 2009.

SHEPHERD, G.J. FITOPAC 2.1 (versão preliminar). Campinas: Universidade Estadual de Campinas, Departamento de Biologia Vegetal, 2009.

TABARELLI, M.; MANTOVANI, W. A regeneração de uma floresta tropical montana após corte e queima (São Paulo - Brasil).

Revista Brasileira de Biologia, v.59, n.2, p.239-250, 1999.

TOTHMERESZ, B. Comparison of different methods for diversity ordering. Journal of Vegetation Science, v.6, p.283-290, 1995.

WHITMORE, T.C. Canopy gaps and two major groups of forest trees. Ecology, v.70, n.3, p.536538,1989 .

YOUNG, C.E.F. Desmatamento e desemprego rural na Mata Atlântica. Floresta e Ambiente, v.13, n.2, p.75-88, 2006.

ZAR, J.H. Bioestatistical analysis. New Jersey: Prentice-Hall, 1996. 